\title{
Texture profile of surimi-like material from mechanically deboned turkey meat
}

\author{
Perfil de textura de concentrados proteicos tipo surimi \\ elaborados com carne mecanicamente separada de peru
}

\author{
Armando Abel Massingue ${ }^{1,2^{\star}}$ (D), Mariele Maria de Oliveira Paula ${ }^{1}$, Ana Paula Rocha ${ }^{1}$, \\ Gabriela de Barros Silva Haddad', Eloá Lourenço do Carmo', \\ Alcinéia de Lemos Souza Ramos ${ }^{1}$, Eduardo Mendes Ramos ${ }^{1}$ \\ ${ }^{1}$ Universidade Federal de Lavras (UFLA), Departamento de Ciência dos Alimentos, Lavras/MG, Brasil \\ ${ }^{2}$ Universidade Eduardo Mondlane (UEM), Escola Superior de Desenvolvimento Rural (ESUDER), \\ Vínculos/Inhambane, Moçambique.
}

${ }^{*}$ Corresponding Author: Armando Abel Massingue, Universidade Eduardo Mondlane (UEM), Escola Superior de Desenvolvimento Rural (ESUDER), C.P. 1304, Vilankulo, Inhambane, Moçambique, e-mail: armandomassingue@gmail.com

Cite as: Massingue, A. A., Paula, M. M. O., Rocha, A. P., Haddad, G. B. S., Carmo, E. L., Ramos, A. L. S., \& Ramos, E. M. (2021). Texture profile of surimi-like material from mechanically deboned turkey meat. Brazilian Journal of Food Technology, 24, e2019345. https://doi.org/10.1590/1981-6723.34519

\begin{abstract}
The study aimed to evaluate the textural properties of turkey surimi-like (TSL) gels from mechanically deboned turkey meat (MDTM) by washing procedures. The effects of water, sodium chloride, sodium bicarbonate, and potassium phosphate buffer washing solutions, cycles, and salt addition were investigated. Sodium bicarbonate washing solution produced lightened and whitened cooked gels. Addition of salt reduced $(p<0.05)$ cooking loss and increased $(p<0.05)$ hardness and chewiness. TSL gels from sodium bicarbonate had the lowest $(p<0.05)$ cooking loss and hardness, and increased $(p<0.05)$ adhesiveness after two washing cycles. Scanning electron micrographs showed fine-stranded gel structures formed at low ionic strength and coarsely aggregated gel structures at high ionic strength. Salt addition improved the TSL gelling properties. Two washing cycles of MDTM with sodium bicarbonate solution generate high-quality colorless gels of TSL with proper textural properties and could be suggested as an alternative meat source in the manufacturing of surimi-based foodstuffs.
\end{abstract}

Keywords: Protein concentrate; Thermal gelation; CIE Color; Scanning electron microscopy; Washing cycles; Washing solutions.

\section{Resumo}

O estudo foi realizado com o objetivo de avaliar o perfil de textura de produtos tipo surimi (TSL) obtidos por três lavagens da carne de peru mecanicamente separada (MDTM). Efeitos de tratamentos com soluções de lavagem com água, cloreto de sódio, bicarbonato de sódio e tampão fosfato de potássio, ciclos de lavagem e adição de sal de cozinha foram investigados. A solução de lavagem com bicarbonato de sódio produziu géis mais claros, resultando em maiores valores de luminosidade $\left(L^{\star}\right)$. A adição de sal contribuiu para redução significativa $(p<0,05)$ das perdas por cozimento e aumentou $(p<0,05)$ a dureza e a mastigabilidade de todos os géis cozidos. No entanto, a solução de bicarbonato de sódio foi a que apresentou mais influência significativa na redução de perdas e dureza 
após cozimento $(p<0,05)$ e aumento da adesividade $(p<0,05)$ mesmo após dois ciclos de lavagem. As micrografias obtidas com ajuda do microscópio eletrônico de varredura mostraram estruturas deformadas por uma pequena linha de rotura em géis com baixa força iônica (sem sal) e estruturas de gel grosseiramente agregadas com alta força iônica (com sal), tendo a adição de sal melhorado as propriedades gelificantes de TSL. Pode-se afirmar que dois ciclos de lavagem de MDTM com solução de bicarbonato de sódio resultaram em géis com boas características de qualidade e de textura adequadas, podendo ser sugeridos como fonte alternativa de carne na fabricação de alimentos à base de surimi.

Palavras-chave: Concentrado proteico; Gelificação térmica; Cor instrumental; Microscopia eletrônica de varredura; Ciclos de lavagens; Soluções de lavagem.

\section{Introduction}

Mechanically deboned turkey meat (MDTM) is a common ingredient in meat products, but its dark color, textural properties, and susceptibility to lipid oxidation are undesirable in meat processing. Washing cycles can be used to reduce these problems and obtain products characterized as "surimi-like", similarly to the washing process traditionally used in fish to produce "surimi" (Tina et al., 2010). Almost all surimi and surimi-like materials are manufactured by repeatedly chilled water-washing to remove undesirable substances, such as sarcoplasmic proteins, lipids, and lower molar water-soluble materials, leaving a tasteless and odorless myofibrillar protein product with unique textural properties (Stine et al., 2012).

There have been profound interests in approaches such as washing cycles using water (Ball \& Montejano, 1984; Massingue et al., 2019) and weak ionic strength solutions like phosphate buffer solution with pH 5.8 to 8.0 (Massingue et al., 2019; Hernandez et al., 1986; Elkhalifa et al., 1988), $0.1 \mathrm{M} \mathrm{NaCl}$ (Massingue et al., 2019; Froning \& Niemann, 1988; Min \& Lee, 2004), and 0.5\% $\mathrm{NaHCO}_{3}$ (Ball \& Montejano, 1984; Dawson et al., 1989; Massingue et al., 2019) in the production of mechanically deboned poultry surimi-like materials.

Recently, other studies found that all selected washing treatments were effective for the removal of heme pigments (Yang \& Froning, 1992; Ng \& Huda, 2011; Ramadhan, Huda \& Ahmad, 2014), obtaining high myofibrillar protein concentration. Like fish surimi, surimi-like from poultry meat has been rarely studied as food materials (Lin \& Chen, 1989; Yang \& Froning, 1992; Ramadhan et al., 2014; Massingue et al., 2019). The textural characteristics and stability surimi-like from poultry meat depend on the inherent characteristics of its proteins, as well as on external factors; primarily temperature, $\mathrm{pH}$, protein concentration and added salt (Park, 2014; Dihort-García et al., 2016).

Protein gelation is an important feature in food because it determines its sensorial properties, especially its texture, which influences consumer acceptance (Tolano-Villaverde et al., 2016). There is plenty of information on the effect of salt addition on thermal gelation properties of myofibrillar proteins (Park et al., 1996; Tornberg, 2005; Kim \& Park, 2008). Highlights are given for commonly $1.2 \%$ to $2.0 \%$ added salt in the commercial surimi. However, the use of $2 \%$ added salt in gel testing can be more practical (Park, 2014), since it represents the maximum amount of salt commonly used in cooked meat products. Although Park et al. (1996) reported good gel-forming ability when they used $1.5 \%$ or $3.0 \%$ salt added in beef or pork surimi, Park (2014) pointed that the use of $3 \%$ salt could overestimate the gel quality of the surimi. On the other hand, Sun \& Holley (2011) confirmed that a concentration of $2 \%$ to $3 \%$ of sodium chloride is required to solubilize the myofibrillar proteins to form a good gel. These authors also found evidence to support that solubilization of the myofibrillar proteins is not an absolute necessity, and good gels can be made without salt.

Therefore, this study aimed to investigate the salt added effects on the gelation properties of surimi-like material obtained from different washing solutions and cycles of MDTM. Since there is no published data on the use of salt to evaluate thermal gelation properties of turkey surimi material obtained from different washing solution, the results of this experiment could greatly contribute a new approach into the academic research and poultry industry development by testing this type of materials as a valuable source of protein and low cost food ingredient. 


\section{Material and methods}

\subsection{Preparation of turkey surimi-like gels}

We used the same turkey surimi-like (TSL) materials as described in a previous report (Massingue et al., 2019). One portion of frozen mechanically deboned turkey meat (MDTM; Frozen donated by BRF® Brazil; Jundiaí, São Paulo, Brazil) was thawed in four (4) volumes of different chilled $\left(<5^{\circ} \mathrm{C}\right)$ washing solutions (water; $0.086 \mathrm{M}$ sodium chloride; $0.06 \mathrm{M}$ sodium bicarbonate; and $0.04 \mathrm{M}$ potassium phosphate buffer, $\mathrm{pH}$ 6.8), and homogenized (at $220 \mathrm{rpm}$ ) for ten (10) min using a propeller shaft agitator (Mechanical Agitator Ika, model RW 20, SP Labor, Brazil). After the first stirring time (cycle), the upper layer of fat was removed using a stainless-steel skimmer and the slurry filtered and pressed in cheesecloth to remove excess of water. The remaining residue was re-suspended with four (4) volumes of the original wash solution, homogenized (220 rpm/10min), filtered, and pressed again in cheesecloth (second cycle). These procedures were repeated for obtaining the third cycle. For each washing solution, residues of the three cycles were used as TSL in this experiment.

The twelve (12) different ( 3 washing cycles $\mathrm{x} 4$ washing solutions) heat-set gel preparations were conducted with an original (without salt addition) and sol (with $2 \%$ salt addition) TSL material. Each TSL (with and without salt) was homogenized in a cutter mixer (Philips Walita, ProMix) for thirty seconds (30 s) until the mixture resembled a meat batter. The temperature of the mixture was kept below $5{ }^{\circ} \mathrm{C}$ during mixing. 25 grams samples were weighed into $50 \mathrm{~mL}$ centrifuge tubes, centrifuged at $3,000 \mathrm{~g}$ for fifteen (15) minutes to compact the batter and sustained at $4{ }^{\circ} \mathrm{C}$ for one (1) hour to equalize their temperature. The tubes were put in a water bath initially at a temperature of $35^{\circ} \mathrm{C}$, then the bath temperature was set to $75^{\circ} \mathrm{C}$ and the sample core temperature was accompanied by a thermocouple (MT525 thermometer, Minipa industry Co., Ltd., São Paulo, Brazil) until reaches $71^{\circ} \mathrm{C}$ (cooking time mean of $30 \mathrm{~min}$ ). Heat-set gels were immediately chilled in ice water bath for fifteen (15) minutes, and the exudates were drained. Paper towels were used to remove any remaining moisture on the gel surface and the final weight was recorded to determine the cooking loss.

\subsection{Texture profile analysis}

The texture profile was performed as described by Ramos \& Gomide (2017) using a TA.XT2i universal texture analyzer (Stable Micro Systems Ltd., Surrey, England). Gels were cut into cylinders (1.5 cm diameter x $1.5 \mathrm{~cm}$ height) and compressed twice to $60 \%$ deformation of their original height with a flat cylindrical compression aluminum probe ( $36 \mathrm{~mm}$ diameter). A crosshead speed of $180 \mathrm{~mm} / \mathrm{min}$ was applied and there was no time of rest between the two compression cycles. Force time curves were recorded during compression and texture attributes were calculated as follows: 1) hardness (N); peak force required for the first compression; 2) springiness $(\mathrm{mm})$; distance sample recovered after the first compression; 3) adhesiveness $(\mathrm{N} \times \mathrm{mm})$; the negative force area for the first bite representing the work necessary to pull the compressing plunger away from the sample 4) cohesiveness; ratio of positive force area during the second compression to that in the first compression and 5) chewiness ( $\mathrm{N} \times \mathrm{mm})$, the product of hardness, cohesiveness, and springiness.

\subsection{CIE color and microstructural analysis}

CIE color and microstructural analysis were carried out to visual assessment of the gel color and microstructure. These analyses were conducted in TSL samples obtained after the second washing cycle. This step was previously reported by Massingue et al. (2019), who have suggested that two washing cycles were sufficient for obtaining surimi-like materials with good technological properties.

The Gels CIE colors were evaluated using a Minolta CM-700 (Konica Minolta Sensing Inc. Osaka, Japan) colorimeter with $8-\mathrm{mm}$ aperture size, illuminant $\mathrm{A}$, a $10^{\circ}$ angle of the observer and specular component excluded (SCE) mode. The CIE lightness $\left(\mathrm{L}^{*}\right)$, redness $\left(\mathrm{a}^{*}\right)$ and yellowness $\left(\mathrm{b}^{*}\right)$ components were obtained on the internal surface of three cylinders cores (25-mm height) from each sample. CIE color coordinates were 
expressed on the CIELCH system with chroma $\left(\mathrm{C}^{*}\right)$ and hue angle (h, degrees) calculated as: $\mathrm{C}^{*}=\left(\mathrm{a}^{* 2 \backslash}+\mathrm{b}^{* 2}\right)^{0.5}$ and $\mathrm{h}=\tan ^{-1}\left(\mathrm{~b}^{*} / \mathrm{a}^{*}\right)$. Higher $\mathrm{C}^{*}$ values suggest more vivid color, and $\mathrm{h}$ values near $0^{\circ}$ are red and near $90^{\circ}$ are yellow (Ramos \& Gomide, 2017). Whiteness as the overall appearance index of the samples was calculated by the formula (Massingue et al., 2019): Whiteness $=100-\left[\left(100-\mathrm{L}^{*}\right)^{2}+\mathrm{a}^{* 2}+\mathrm{b}^{* 2}\right]^{0.5}$.

The microstructural evaluation was conducted by scanning electron microscopy (SEM) analysis as described by Bozzola \& Russel (1999). Cubes of $0.5 \mathrm{~cm}$ length were fixed in Karnovsky's Fixative (buffer solution of sodium cacodylate $0.05 \mathrm{M}, \mathrm{CaCl} 20.001 \mathrm{M}, \mathrm{pH} 7.2$ with $2.5 \%$ paraformaldehyde and $2.0 \%$ glutaraldehyde) at $4{ }^{\circ} \mathrm{C}$ for $24 \mathrm{~h}$. After fixation, samples were dehydrated for $10 \mathrm{~min}$ into a series of $25 \%, 50 \%, 75 \%$ and $90 \%$ acetone (acetone/water, v/v) and three times for $10 \mathrm{~min}$ into $100 \%$ acetone. Samples dehydration was performed by the critical point drying CPD 030 device (BAL-TEC AG, Balzer, Germany), coated with gold using sputtering SCD 050 device (BAL-TEC AG, Balzer, Germany) and observed in a Scanning Electron Microscope LEO EVO 40 (Carl Zeiss, Germany) at $15.02 \mathrm{kV}$ and at a working distance of $7.5 \mathrm{~mm}$.

\subsection{Statistical analysis}

The statistical analysis was conducted in a completely randomized design, with a factorial arrangement of 4 (washing solutions) x 3 (washing cycles) x 2 (salt levels) with 3 repetitions (batches). Main and interaction effects of functional properties were evaluated by ANOVA, and when necessary by Duncan test using software SAS 9.2 (SAS Institute Inc., Cary, NC, USA) package, with a significance level of 5\%.

\section{Results and discussion}

\subsection{Cooking loss and texture profile analyzes}

The effects of washing solutions, washing cycles and salt addition on the cooking loss and texture profile attributes of turkey surimi-like gels are shown in Table 1.

Table 1. Effects (means \pm standard deviation) of washing solutions (WS), washing cycles (WC) and salt level (SL) on cooking loss and texture attributes of turkey surimi-like gels.

\begin{tabular}{|c|c|c|c|c|c|c|}
\hline Effects & $\begin{array}{c}\text { Cooking loss } \\
(\%)\end{array}$ & $\begin{array}{l}\text { Hardness } \\
(\mathbf{N})\end{array}$ & Cohesiveness & $\begin{array}{c}\text { Adhesiveness } \\
(\mathbf{N} \times \mathbf{m m})\end{array}$ & $\begin{array}{c}\text { Springiness } \\
(\mathrm{mm})\end{array}$ & $\begin{array}{l}\text { Chewiness } \\
(\mathbf{N} \times \mathbf{m m})\end{array}$ \\
\hline \multicolumn{7}{|c|}{ Washing solutions (WS) } \\
\hline Water & $24.36 \pm 7.04$ & $45.80 \pm 5.04$ & $0.45 \pm 0.03$ & $0.09 \pm 0.11$ & $26.44 \pm 1.35$ & $538.40 \pm 208.63$ \\
\hline $\mathrm{NaCl}$ & $22.45 \pm 9.25$ & $46.31 \pm 10.57$ & $0.41 \pm 0.02$ & $0.12 \pm 0.09$ & $26.11 \pm 1.53$ & $512.14 \pm 150.55$ \\
\hline $\mathrm{NaHCO}_{3}$ & $10.68 \pm 6.24$ & $25.74 \pm 11.44$ & $0.39 \pm 0.05$ & $0.32 \pm 0.22$ & $25.59 \pm 1.73$ & $296.04 \pm 185.12$ \\
\hline $\mathrm{PO}_{4}$-buffer & $20.48 \pm 8.36$ & $46.28 \pm 12.43$ & $0.41 \pm 0.02$ & $0.07 \pm 0.04$ & $25.73 \pm 1.41$ & $433.49 \pm 161.43$ \\
\hline \multicolumn{7}{|c|}{ Number of washing cycles (WC) } \\
\hline 1 & $18.38 \pm 8.48$ & $44.67 \pm 16.16$ & $0.40 \pm 0.03^{\mathrm{a}}$ & $0.11 \pm 0.07$ & $26.03 \pm 1.81$ & $484.22 \pm 221.26$ \\
\hline 2 & $19.48 \pm 8.92$ & $42.01 \pm 13.68$ & $0.42 \pm 0.05^{\mathrm{ab}}$ & $0.20 \pm 0.24$ & $26.19 \pm 1.33$ & $459.77 \pm 172.32$ \\
\hline 3 & $20.61 \pm 10.63$ & $36.43 \pm 14.81$ & $0.43 \pm 0.03^{\mathrm{b}}$ & $0.14 \pm 0.12$ & $25.67 \pm 1.38$ & $391.06 \pm 194.47$ \\
\hline \multicolumn{7}{|c|}{ Salt level, \% (SL) } \\
\hline 0 & $26.42 \pm 6.66$ & $32.20 \pm 12.02$ & $0.41 \pm 0.04$ & $0.12 \pm 0.11$ & $25.09 \pm 1.37^{\mathrm{a}}$ & $326.41 \pm 158.38$ \\
\hline 2 & $12.56 \pm 5.69$ & $49.86 \pm 12.58$ & $0.42 \pm 0.03$ & $0.18 \pm 0.20$ & $26.84 \pm 1.11^{\mathrm{b}}$ & $563.63 \pm 160.35$ \\
\hline \multicolumn{7}{|c|}{$\operatorname{Pr}>F^{1}$} \\
\hline WS & $<0.001$ & $<0.001$ & $<0.001$ & $<0.001$ & 0.119 & $<0.001$ \\
\hline WC & 0.022 & $<0.001$ & 0.026 & $<0.001$ & 0.270 & $<0.001$ \\
\hline $\mathrm{SL}$ & $<0.001$ & $<0.001$ & 0.045 & $<0.001$ & $<0.001$ & $<0.001$ \\
\hline WSxWC & 0.134 & $<0.001$ & 0.909 & $<0.001$ & 0.361 & $<0.001$ \\
\hline WSxSL & 0.003 & 0.087 & $<0.001$ & $<0.001$ & 0.057 & 0.001 \\
\hline WCxSL & 0.005 & 0.914 & 0.867 & $<0.001$ & 0.073 & 0.906 \\
\hline WSxWCxSL & 0.952 & 0.039 & 0.363 & $<0.001$ & 0.273 & $<0.001$ \\
\hline
\end{tabular}

$\mathrm{NaCl}=$ sodium chloride $0.086 \mathrm{M} ; \mathrm{NaHCO}_{3}=$ sodium bicarbonate $0.06 \mathrm{M}$; and $\mathrm{PO}_{4}$-buffer $=$ Phosphate buffer $0.04 \mathrm{M}(\mathrm{pH} 6.8) .{ }^{1}$ Significant probability $(p<0.05)$ was shown in bold. ${ }^{\text {a-b }}$ Means with different superscript letter, within a column and for each effect, differ $(p>0.05)$. 
For cooking losses, we observed interactions $(p<0.05)$ between salt addition and washing solutions as well as salt addition and washing cycles. Overall, the $2 \%$ added salt decreased $(p<0.05)$ the cooking losses of heat-set gels, independently of the washing solution or the washing cycle applied. The low cooking loss might be mainly a function of protein-protein interaction resulting in an open matrix, thereby allowing a higher proportion of total water to be immobilized than in meat proteins with strong protein interactions (Kang et al., 2007).

Salt solubilizes the myofibrillar proteins, improving its functionality and, therefore, increasing proteinwater and protein-protein binding with better gelation (Kim \& Park, 2008; Desmond, 2006), resulting in cooking losses reduction.

Heat-set gels without salt addition had lower $(p<0.05)$ cooking losses when washed by one or two cycles than by three cycles (Figure 1), which could be due to the lower ionic strength, and lower ability of water binding, and for the lower protein content in surimi-like materials, as observed by Massingue et al. (2019). Thus, the washing process reduced the protein content from $14.76 \%$ with 1 and 2 cycles to $13.19 \%$ with 3 cycles. However, despite a slight increase in cooking loss due to the repeated washes in gels without salt additions, there were no significant differences $(p>0.05)$ in the cooking losses values of $2 \%$ salty surimilike gels.

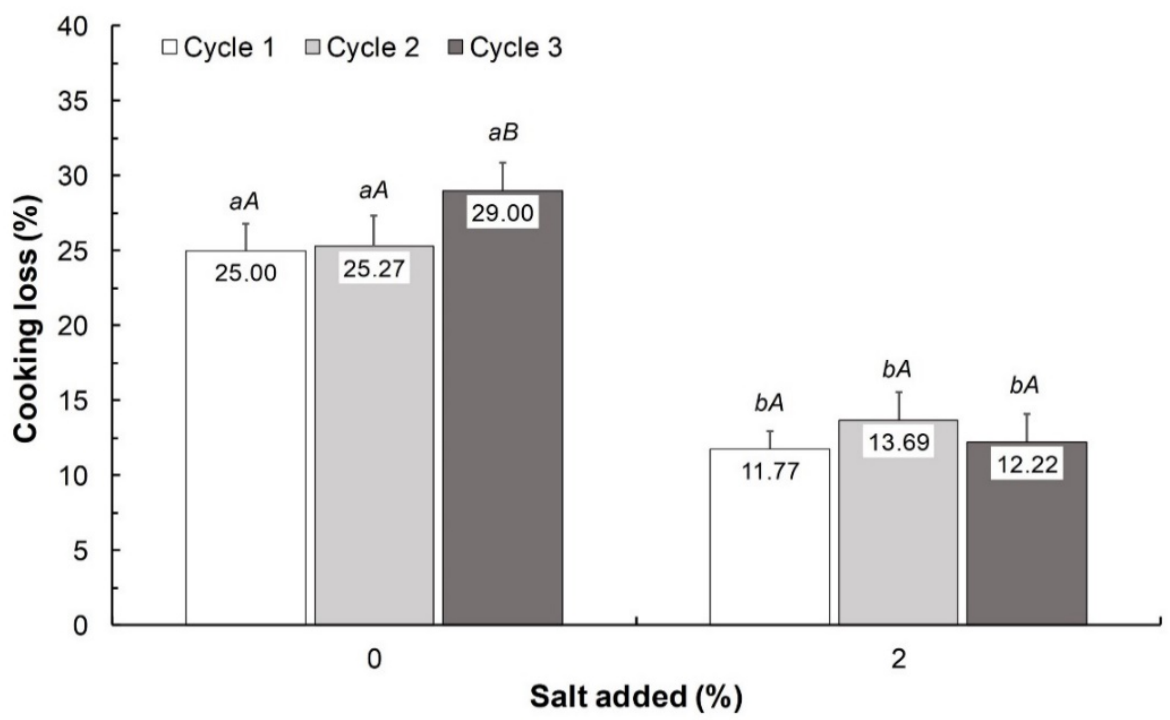

Figure 1. Effects of salt $(\mathrm{NaCl}) \mathrm{x}$ washing cycles interaction on cooking loss of turkey surimi-like gels. Bars (+ standard error of the mean) with a common uppercase letter (A-C), for the same salt level, and lowercase letters (a,b), for the washing solutions or washing cycles, did not differ $(p>0.05)$.

For washing solutions (Figure 2), the cooking losses of surimi-like gels without salt added were lower ( $p$ $<0.05)$ in samples washed by sodium bicarbonate $(16.39 \pm 2.75 \%)$ than in samples washed with other solutions (mean of $29.77 \pm 3.08 \%$ ). In sol (added of $2 \% \mathrm{NaCl}$ ) gels, however, surimi-like obtained by washing with sodium bicarbonate $(4.99 \pm 1.45 \%)$ had lower $(p<0.05)$ cooking loss than sodium chloride and phosphate buffer $(13.28 \pm 2.74 \%)$ and water washed samples $(18.71 \pm 23.91 \%)$. Although a previous study from Massingue et al. (2019) had denoted that protein content was higher in TSL washed with water or sodium chloride $(15.22 \%)$ than that surimi obtained by washing with phosphate buffer $(14.15 \%)$ or sodium bicarbonate $(12.35 \%)$, protein content did not appear to have been responsible for reported differences of cooking losses. Furthermore, those authors reported that samples washed with sodium bicarbonate have higher $\mathrm{pH}$ value and water holding capacity (WHC) than other surimi-like materials, being observed. The inverse was observed for water-washed samples, explaining the differences in cooking loss during gelation observed in this experiment. 


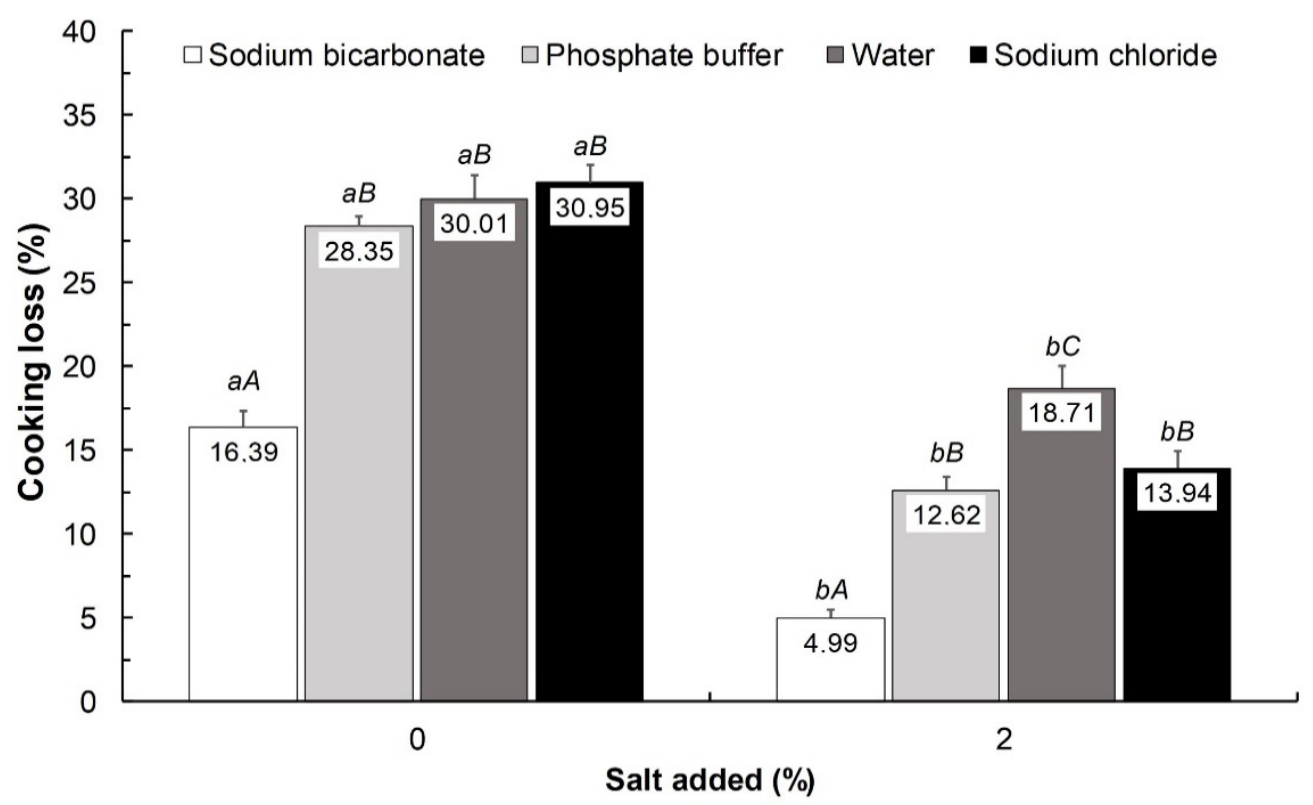

Figure 2. Effects of salt $(\mathrm{NaCl}) \times$ washed solutions interaction on cooking loss of turkey surimi-like gels. Bars (+ standard error of the mean) with a common uppercase letter $\left({ }^{\mathrm{A}-\mathrm{C}}\right)$, for the same salt level, and lowercase letters $\left({ }^{\mathrm{a}, \mathrm{b}}\right)$, for the washing solutions or washing cycles, did not differ $(p>0.05)$.

For the texture profile, we observed a significant triple interaction between all factors for hardness, adhesiveness, and chewiness (Table 1). The results of these interactions were described in Table 2.

Table 2. Effects of a triple interaction (washing solutions $\mathrm{x}$ washing cycles $\mathrm{x}$ salt level) on hardness, adhesiveness, and chewiness of turkey surimi-like gels.

\begin{tabular}{|c|c|c|c|c|c|c|}
\hline \multirow{2}{*}{ Solutions / cycles } & \multicolumn{2}{|c|}{ Hardness (N) } & \multicolumn{2}{|c|}{ Adhesiveness $(\mathbf{N} \times \mathbf{m m})$} & \multicolumn{2}{|c|}{ Chewiness $(\mathbf{N} \times \mathbf{m m})$} \\
\hline & Without salt & $2 \%$ salt & Without salt & $2 \%$ salt & Without salt & $2 \%$ salt \\
\hline \multicolumn{7}{|l|}{ Water } \\
\hline 1 & $51.05 \pm 1.44^{\mathrm{Aa}}$ & $71.66 \pm 5.06^{\mathrm{Ab}}$ & $0.08 \pm 0.03^{\mathrm{Aa}}$ & $0.05 \pm 0.01^{\mathrm{Aa}}$ & $640.47 \pm 59.51^{\mathrm{Aa}}$ & $880.01 \pm 36.98^{\mathrm{Ab}}$ \\
\hline 2 & $40.37 \pm 0.22^{\mathrm{Ba}}$ & $48.83 \pm 5.23^{\mathrm{Ba}}$ & $0.02 \pm 0.01^{\mathrm{Aa}}$ & $0.03 \pm 0.01^{\mathrm{Aa}}$ & $519.91 \pm 19.67^{\mathrm{Ba}}$ & $555.61 \pm 88.15^{\mathrm{Ba}}$ \\
\hline 3 & $27.22 \pm 9.13^{\mathrm{Ca}}$ & $35.69 \pm 3.17^{\mathrm{Ca}}$ & $0.08 \pm 0.02^{\mathrm{Aa}}$ & $0.04 \pm 0.03^{\mathrm{Aa}}$ & $260.85 \pm 42.57^{\mathrm{Ca}}$ & $373.57 \pm 36.28^{\mathrm{Ca}}$ \\
\hline \multicolumn{7}{|l|}{$\mathrm{NaCl}$} \\
\hline 1 & $43.47 \pm 0.28^{\mathrm{Aa}}$ & $55.94 \pm 5.57^{\mathrm{Ab}}$ & $0.13 \pm 0.04^{\mathrm{Aa}}$ & $0.11 \pm 0.03^{\mathrm{Ab}}$ & $398.61 \pm 41.23^{\mathrm{Aa}}$ & $626.79 \pm 90.65^{\mathrm{Ab}}$ \\
\hline 2 & $36.18 \pm 3.02^{\mathrm{Ba}}$ & $55.85 \pm 2.08^{\mathrm{Ab}}$ & $0.10 \pm 0.01^{\mathrm{Aa}}$ & $0.11 \pm 0.02^{\mathrm{Ab}}$ & $359.32 \pm 44.48^{\mathrm{Aa}}$ & $660.91 \pm 39.25^{\mathrm{Ab}}$ \\
\hline 3 & $32.10 \pm 7.66^{\mathrm{Ba}}$ & $54.33 \pm 2.59^{\mathrm{Ab}}$ & $0.25 \pm 0.14^{\mathrm{Ba}}$ & $0.21 \pm 0.09^{\mathrm{Bb}}$ & $403.32 \pm 80.08^{\mathrm{Aa}}$ & $623.86 \pm 55.08^{\mathrm{Ab}}$ \\
\hline \multicolumn{7}{|l|}{$\mathrm{NaHCO}_{3}$} \\
\hline 1 & $17.78 \pm 1.99^{\mathrm{Aa}}$ & $36.81 \pm 1.31^{\mathrm{Ab}}$ & $0.12 \pm 0.03^{\mathrm{Aa}}$ & $0.25 \pm 0.04^{\mathrm{Ab}}$ & $144.34 \pm 12.58^{\mathrm{Aa}}$ & $415.86 \pm 16.32^{\mathrm{Ab}}$ \\
\hline 2 & $14.74 \pm 3.27^{\mathrm{Aa}}$ & $41.18 \pm 7.76^{\mathrm{Ab}}$ & $0.25 \pm 0.04^{\mathrm{Ba}}$ & $0.55 \pm 0.19^{\mathrm{Bb}}$ & $132.96 \pm 18.10^{\mathrm{Aa}}$ & $434.52 \pm 96.52^{\mathrm{Bb}}$ \\
\hline 3 & $14.89 \pm 2.94^{\mathrm{Aa}}$ & $29.05 \pm 3.98^{\mathrm{Bb}}$ & $0.29 \pm 0.13^{\mathrm{Ba}}$ & $0.42 \pm 0.08^{\mathrm{Bb}}$ & $140.17 \pm 32.82^{\mathrm{Aa}}$ & $408.41 \pm 48.04^{\mathrm{ABb}}$ \\
\hline \multicolumn{7}{|l|}{$\mathrm{PO}_{4}$-buffer } \\
\hline 1 & $30.88 \pm 3.54^{\mathrm{Aa}}$ & $49.78 \pm 8.86^{\mathrm{Ab}}$ & $0.03 \pm 0.02^{\mathrm{Aa}}$ & $0.10 \pm 0.03^{\mathrm{Aa}}$ & $297.14 \pm 40.40^{\mathrm{Aa}}$ & $470.59 \pm 0.09^{\mathrm{Ab}}$ \\
\hline 2 & $40.30 \pm 8.02^{\mathrm{Ba}}$ & $58.63 \pm 5.56^{\mathrm{ABb}}$ & $0.09 \pm 0.04^{\mathrm{Aa}}$ & $0.09 \pm 0.08^{\mathrm{Aa}}$ & $348.65 \pm 26.95^{\mathrm{Aa}}$ & $496.28 \pm 79.73^{\mathrm{Ab}}$ \\
\hline 3 & $37.44 \pm 5.38^{\mathrm{Ba}}$ & $60.68 \pm 3.64^{\mathrm{Bb}}$ & $0.05 \pm 0.01^{\mathrm{Aa}}$ & $0.05 \pm 0.01^{\mathrm{Aa}}$ & $271.23 \pm 12.90^{\mathrm{Aa}}$ & $617.09 \pm 76.34^{\mathrm{Bb}}$ \\
\hline
\end{tabular}

$\mathrm{NaCl}=$ sodium chloride $0.086 \mathrm{M} ; \mathrm{NaHCO}_{3}=$ sodium bicarbonate $0.06 \mathrm{M}$; and $\mathrm{PO}_{4}$-buffer $=$ Phosphate buffer $0.04 \mathrm{M}(\mathrm{pH} 6.8) .{ }^{\mathrm{A}-\mathrm{C}} \mathrm{Means}$ with the different superscript letter, within a column and for each washing solution, differ $(p>0.05)$. ${ }^{\mathrm{a}-\mathrm{b}}$ Means with the different superscript letter, within a row and for each texture attribute, differ $(p>0.05)$. 
Overall, the hardness and chewiness of the heat-set gels were positively affected by salt addition. For both attributes (hardness and chewiness), the profile observed was similar to cooking loss values, with samples that have higher cooking loss presenting higher hardness and chewiness values. Moreover, lower gel strength (lower hardness and chewiness) for sodium bicarbonate gels can be attributed to the high moisture and low protein content into the surimi-like material as previous reported (Massingue et al., 2019). The protein content is responsible for the hardness, as rheological parameters are strongly influenced by protein concentration in processed muscle foods (Colmenero et al., 1995). Also, if the water content is too high, gels will be weak (Park, 2014; Lanier et al., 2005). These results agreed with previous reports concerning poultry surimi-like gel-forming (Yang \& Froning, 1992; Ramadhan et al., 2014). Moreover, according to Ramadhan et al. (2014), when washing increases the hardness, the values for chewiness were high as well.

Although hardness and chewiness from samples washed with sodium chloride, sodium bicarbonate, and phosphate buffer were not affected $(p>0.05)$ by repeated washings when gelling without salt, they decreased $(p<0.05)$ after three washing cycles when sol was prepared with $2 \%$ salt before the gelling process. Otherwise, samples from water-washed surimi-like presented a reduction $(p<0.05)$ in the values of these attributes (hardness and chewiness), with washing cycles, independently of the addition of salt. These reductions were also related to the cooking loss values in samples cooked without salt, but not in the sol TSL samples. Ng \& Huda (2011) observed that an increasing number of washing cycles with water, sodium bicarbonate, sodium chloride, and sodium phosphate buffer solutions increased hardness for duck surimi gel. However, Jin et al. (2007) did not find significant differences between chicken surimi gel strength due to the repeated washings.

The adhesiveness increased $(p<0.05)$ due to washing cycles for sodium chloride and sodium bicarbonate washed samples while water and phosphate did not $(p<0.05)$ promote changes in adhesiveness. The most significant effect $(p<0.05)$ of adhesiveness values was that observed for gels from sodium bicarbonate which increased mainly after two washes.

For cohesiveness (overall binding), an interaction between washing solutions and salt added was found. When salt was not added, the cohesiveness of water-washed surimi-like gels $(0.47 \pm 0.04)$ were higher $(p<$ $0.05)$ than sodium chloride and phosphate buffer $(0.40 \pm 0.02)$ and sodium bicarbonate $(0.36 \pm 0.02)$ ones (Figure 3). As observed for hardness and chewiness, this behavior was very similar to the cooking loss values (Figure 2) and could be related to the protein content. However, when $2 \%$ of salt was added, we observed no difference $(p>0.05)$ between samples due to the washing solution used $(0.43 \pm 0.03)$.

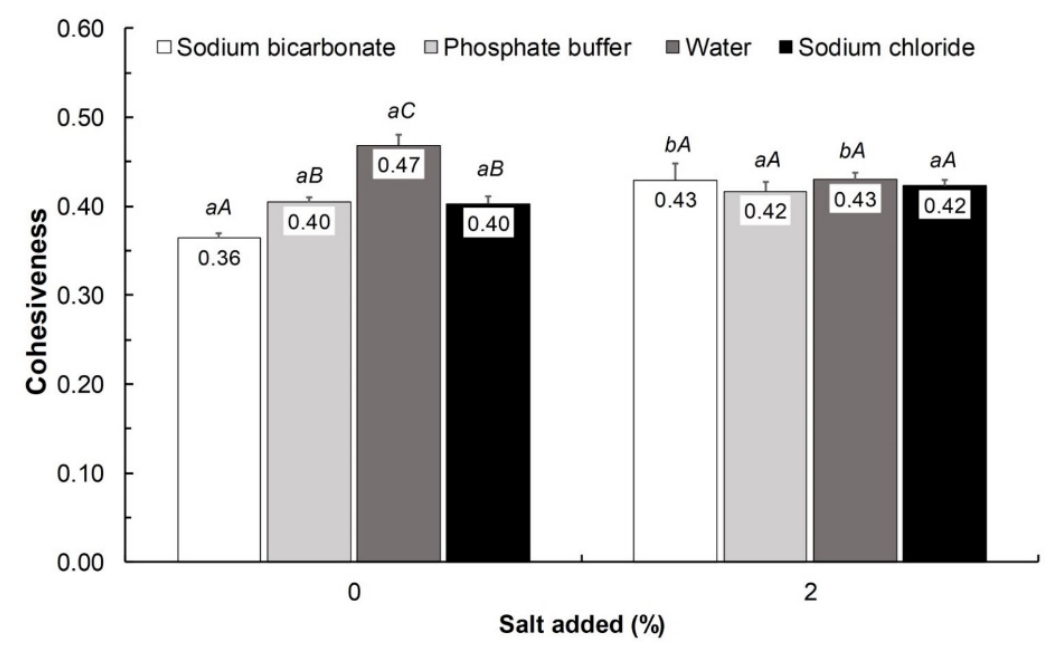

Figure 3. Effects of salt $(\mathrm{NaCl}) \mathrm{x}$ washed solutions interaction on the cohesiveness of turkey surimi-like gels. Bars (+ standard error of the mean) with a common uppercase letter (A-C), for the same salt level, and lowercase letters $(a, b)$, for the washing solutions or washing cycles, did not differ $(p>0.05)$.

As previously described by solubilizing the meat proteins, the salt improved the protein-protein binding (Desmond, 2006) and, therefore, the cohesiveness of the batter.

The cohesiveness values were also affected $(p<0.05)$ by washing cycles, increasing from the first to the third washes (Table 1). According to Pietrasik (1999), fat reduction causes an increase in cohesiveness values 
of meat products. This explains the increase in the cohesiveness values since a reduction in the fat content of the turkey surimi-like was observed with higher washing cycles (Massingue et al., 2019).

Springiness values were not affected $(p>0.05)$ by the washing solutions or washing cycles $(25.97 \pm 1.51 \mathrm{~mm})$. Contrary, Yang \& Froning (1992) found differences among gels as affected by washing solutions, in which water and sodium bicarbonate washed gels presented lower springiness. However, springiness had slightly enhanced $(p<0.05)$ by salt addition (Table 1$)$, as observed for the other texture attributes.

These facts confirm that reports from Park et al. (1996) that the addition of $\mathrm{NaCl}$ at $1.5-3.0 \%$ improves gel strength properties of surimi-like from beef or pork. Moreover, because of the high surimi myofibrillar protein concentration, when mixed with salt and cooked, surimi forms a strong gel with an elastic, chewy texture. Salt improves the WHC of the meat proteins, promote protein destabilization and denaturation, and can cause protein aggregation prior to network formation during heat treatment (Kim \& Park, 2008), and could be predicted to improve gelation ability.

\subsection{Heat-set gels microstructures}

The scanning electron micrographs (SEM) of cooked turkey surimi-like gels from eight different types of extracted surimi-like material could be seen in Figure 4. Structural changes of proteins during gel formation allow the development of a three-dimensional network that supports the formed gel. Added salt favored protein aggregation. This difference in salt concentration $(0$ and $2 \%)$ also seems to be the main factor for protein structural changes in the meat proteins. From SEM images, we observed improvements in the network structure with $2 \%$ added salt, which reflects in the gel strength (revealed by TPA parameters). The microstructure of myofibrillar proteins gelation was affected by ionic strength: at low ionic strength (gels without salt), finestranded gel structures were formed; at high ionic strength (gels with salt) coarsely aggregated gel structures were formed. Finally, the difference in the network gel of surimi-like material was observed in samples washed with sodium bicarbonate, especially in samples without salt in which the sodium bicarbonate treatment seems to have a more compact arrangement, however this treatment was soft (less hard) and less cohesive compared to that obtained by washing with water, sodium bicarbonate and potassium phosphate buffer.

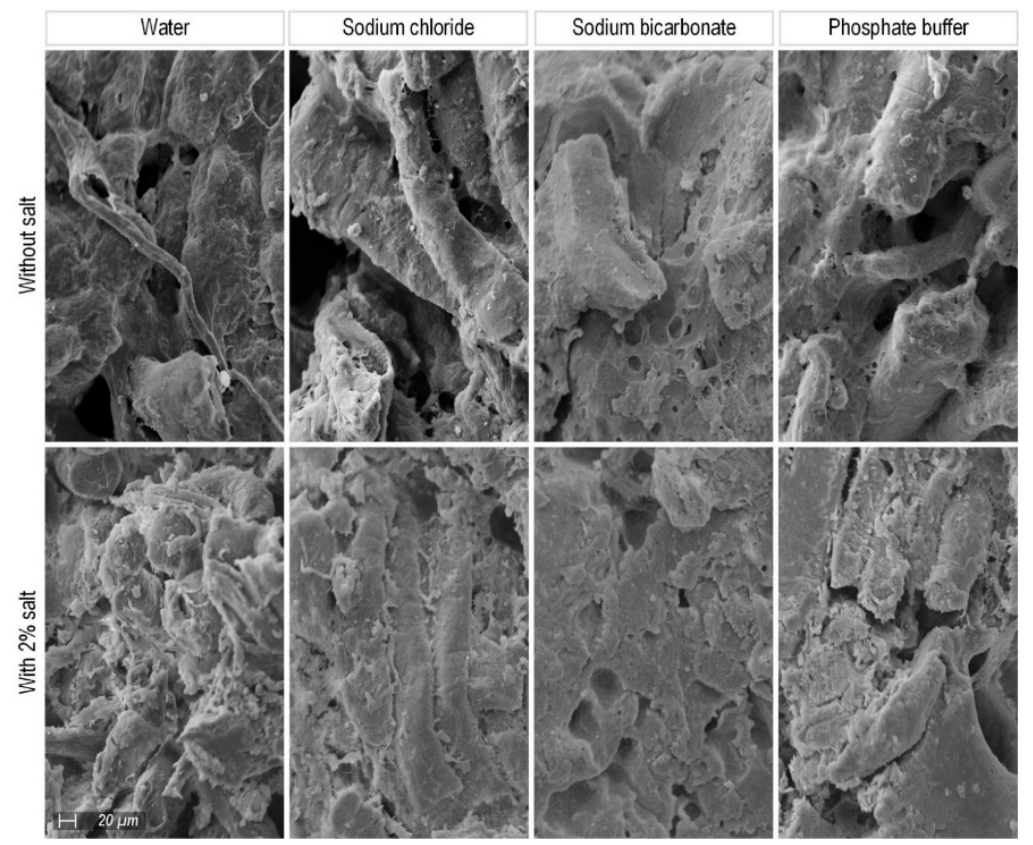

Figure 4. Scanning electron micrographs (SEM; magnification 500x) of gels from turkey surimi-like washed by two cycles with water, sodium chloride $(\mathrm{NaCl} 0.086 \mathrm{M})$, sodium bicarbonate $\left(\mathrm{NaHCO}_{3} 0.06 \mathrm{M}\right)$, and potassium phosphate buffer $(0.04 \mathrm{M} ; \mathrm{pH}=6.8)$, with $(2 \%)$ or without salt $(\mathrm{NaCl})$ addition. 


\subsection{Heat-set gels CIE color}

Figure 5 illustrates the color of heat-set gels of TSL obtained from MDTM by different washing solutions after two washing cycles. Overall, the perceptible differences in the color of gels confirm the differences observed previously by Massingue et al. (2019) in the color of protein concentrate (TSL) after different washed cycles and solutions. As can see by the pictures, sodium bicarbonate followed by phosphate buffer washed samples were lighter (higher $\mathrm{L}^{*}$ values) and whiter (higher whiteness values) colored material, more yellowish (higher $\mathrm{h}$ values) but with less intense (lower $\mathrm{C}^{*}$ values) color than other samples. These should be related to the high heme pigment removal during the washing process in the elaboration of TSL, particularly when sodium bicarbonate was used. According to Jin et al. (2007), lightness and whiteness are particularly important quality attributes of surimi.
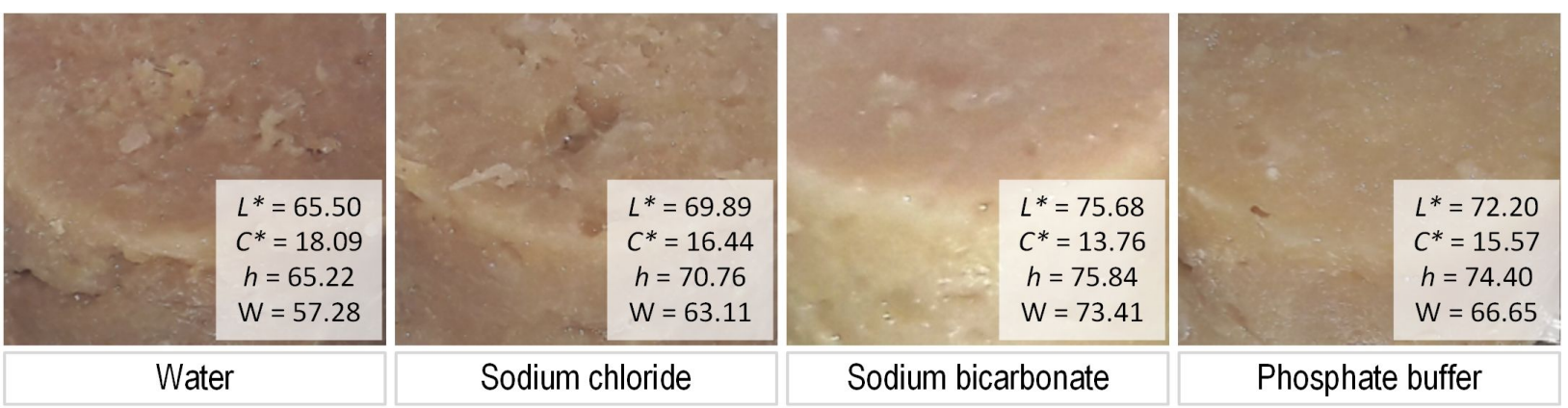

Figure 5. Pictures and CIELCH values of gels from turkey surimi-like washed two cycles with water, sodium chloride $(\mathrm{NaCl} 0.086 \mathrm{M})$, sodium bicarbonate $\left(\mathrm{NaHCO}_{3} 0.06 \mathrm{M}\right)$, and potassium phosphate buffer $(0.04 \mathrm{M} ; \mathrm{pH}=6.8)$. $\mathrm{L}^{*}=$ lightness; $\mathrm{C}^{*}=$ chroma; $\mathrm{h}$ (degrees) $=$ hue angle; and $\mathrm{W}=$ whiteness.

\section{Conclusion}

The use of water, sodium chloride $(\mathrm{NaCl})$, sodium bicarbonate $\left(\mathrm{NaHCO}_{3}\right)$ and potassium phosphate buffer in surimi-like materials (TSL) obtained by the washing of the mechanically deboned turkey meat presented different effects on the gel properties. Preparing TSL sol (addition of $2 \%$ salt) before gelling process improved the gel's overall texture. Washing with $\mathrm{NaHCO}_{3}$ reduced the gel strength, but resulted in the lower cooking loss and lighter colorless material. Thus, the use of $\mathrm{NaHCO}_{3}$ solution with two washes cycle could be a potential alternative to obtain TSL with proper textural properties to be used in the manufacture of surimi-based foodstuffs, such as poultry meat products.

\section{Acknowledgements}

The authors would like to thank the Brazilian funding agencies Conselho Nacional de Desenvolvimento Científico e Tecnológico (CNPq; 430206/2016-0) and the Fundação de Amparo à Pesquisa do Estado de Minas Gerais (FAPEMIG; CVZ APQ-02015-15 and CVZ APQ-02904-17) for their financial support. The authors are also grateful to the Government of Mozambique and the Brazilian agency Coordenação de Aperfeiçoamento de Pessoal de Nível Superior (CAPES) for the scholarship granting to the first author (Doctorate; PEC-PG/CAPES).

\section{References}

Ball, H. R. J., \& Montejano, J. G. (1984). Composition of washed broiler thigh meat. Poultry Science, 63, 60-63.

Bozzola, J. J., \& Russel, L. D. (1999). Electron microscopy: principles and techniques for biologists (670 p.). Boston: Jones and Bartlett. 
Colmenero, F. J., Barreto, G., Mota, N., \& Carballo, J. (1995). Influence of protein and fat content and cooking temperature on texture and sensory evaluation of bologna sausage. Lebensmittel-Wissenschaft + Technologie, 28(5), 481-487. http://dx.doi.org/10.1006/fstl.1995.0081

Dawson, P. L., Sheldon, B. W., \& Ball Junior, H. R. J. (1989). A pilot-plant washing procedure to remove fat and color components from mechanically deboned chicken meat. Poultry Science, 68(6), 749-753. http://dx.doi.org/10.3382/ps.0680749

Desmond, E. (2006). Reducing salt: a challenge for the meat industry. Meat Science, 74(1), 188-196. PMid:22062728. http://dx.doi.org/10.1016/j.meatsci.2006.04.014

Dihort-García, G., Tolano-Villaverde, I. J., Ezquerra-Brauer, J. M., Ocaño-Higuera, V. M., Ramírez De León, J. A., TorresArreola, W., \& Marquez-Rios, E. (2016). Effects of pH and sodium chloride on the gelling properties of a protein concentrate obtained from Jumbo Squid Mantle (Dosidicus gigas). International Journal of Food Properties, 19(2), 314-325. http://dx.doi.org/10.1080/10942912.2015.1021930

Elkhalifa, E. A., Graham, P. P., Marriott, N. G., \& Phelps, S. K. (1988). Color characteristics and functional properties of flaked turkey dark meat as influenced by washing treatments. Journal of Food Science, 53(4), 1068-1071. http://dx.doi.org/10.1111/j.1365-2621.1988.tb13532.x

Froning, G. W., \& Niemann, L. M. (1988). Effect of washing of mechanically deboned chicken meat on composition and functional properties. Poultry Science, 67, 87-90.

Hernandez, A., Baker, R. C., \& Hotchkiss, J. H. (1986). Extraction of pigments from mechanically deboned turkey meat. Journal of Food Science, 51(4), 865-867. http://dx.doi.org/10.1111/j.1365-2621.1986.tb11186.x

Jin, S., Kim, I., Kim, S., Jeong, K., Choi, Y., \& Hur, S. (2007). Effect of muscle type and washing times on physicochemical characteristics and qualities of surimi. Journal of Food Engineering, 81(3), 618-623.

http://dx.doi.org/10.1016/j.jfoodeng.2007.01.001

Kang, G. H., Yang, H. S., Jeong, J. Y., Moon, S. H., Joo, S. T., \& Park, G. B. (2007). Gel properties of surimi-like materials from the cardiac and skeletal muscle of pigs. Asian-Australasian Journal of Animal Sciences, 20(8), 1292-1296.

http://dx.doi.org/10.5713/ajas.2007.1292

Kim, Y. S., \& Park, J. W. (2008). Negative roles of salt in gelation properties of fish protein isolate. Journal of Food Science, 73(8), C585-C588. PMid:19019100. http://dx.doi.org/10.1111/j.1750-3841.2008.00900.x

Lanier, T., Carvajal, P., \& Yongsawatdigul, J. (2005). Surimi gelation chemistry. In J. W. Park (Ed.), Surimi and surimi seafoods. (2nd ed., pp. 435-489). Boca Raton: Taylor \& Francis.

Lin, S. W., \& Chen, T. C. (1989). Yields, color and compositions of washed, kneaded and heated mechanically deboned poultry meat. Journal of Food Science, 54(3), 561-563. http://dx.doi.org/10.1111/j.1365-2621.1989.tb04651.x

Massingue, A. A., Torres Filho, R. A., Fontes, P. R., Asaam, S., Gomes, M. E. S., Ramos, A. L.S. \& Ramos, E. M. (2019). Effect of washing cycles and solutions on chemical composition and physicochemical properties of the surimi-like material from mechanically deboned turkey meat. Journal of Food Processing and Preservation, 53(5), 1-11. http://dx.doi.org/10.1111/jfpp.13929.

Min, B. J., \& Lee, S. K. (2004). Surimi quality from mechanically deboned chicken meat as affected by washing cycle, salt concentration, heating temperature and rate. Asian-Australasian Journal of Animal Sciences, 17(1), 131-136. http://dx.doi.org/10.5713/ajas.2004.131

Ng, X. Y., \& Huda, N. (2011). Thermal gelation properties and quality characteristics of duck surimi-like material (duckrimi) as affected by the selected washing processes. International Food Research Journal, 18(2), 731-740. Retrieved in 2020, September 15, from http://www.ifrj.upm.edu.my/18\%20(02)\%202011/(36)\%20IFRJ-2010-169.pdf

Park, J. W. (2014). Surimi and surimi seafood (3rd ed.). Boca Raton: Taylor \& Francis.

Park, S., Brewer, M. S., Mckeith, F. K., Bechtel, P. J., \& Novakofski, J. (1996). Salt, cryoprotectants and preheating temperature effects on surimi-like material from beef or pork. Journal of Food Science, 61(4), 790-795. http://dx.doi.org/10.1111/j.13652621.1996.tb12204.x

Pietrasik, Z. (1999). Effect of content of protein, fat and modified starch on binding textural characteristics, and colour of comminuted scalded sausages. Meat Science, 51(1), 17-25. PMid:22061532. http://dx.doi.org/10.1016/S0309-1740(98)00068-0

Ramadhan, K., Huda, N., \& Ahmad, R. (2014). Effect of number and washing solutions on functional properties of the surimi-like material from duck meat. Journal of Food Science and Technology, 51(2), 256-266. PMid:24493882. http://dx.doi.org/10.1007/s13197-011-0510-1

Ramos, E. M., \& Gomide, L. A. M. (2017). Avaliação da qualidade de carnes: fundamentos e metodologias (2. ed.). Viçosa: Editora UFV.

Stine, J. J., Pedersen, L., Smiley, S., \& Bechtel, P. J. (2012). Recovery and utilization of protein derived from surimi wash-water. Journal of Food Quality, 35(1), 43-50. http://dx.doi.org/10.1111/j.1745-4557.2011.00424.x

Sun, X. D., \& Holley, R. A. (2011). Factors Influencing Gel Formation by Myofibrillar Proteins in Muscle Foods. Comprehensive Review in Food Science, 10(1), 33-51. http://dx.doi.org/10.1111/j.1541-4337.2010.00137.x

Tina, N., Nurul, H., \& Ruzita, A. (2010). Surimi-like material: challenges and prospects. International Food Research Journal, 17(3), 509-517.

Tolano-Villaverde, I. J., Torres-Arreola, W., Ocaño-Higuera, V. M., \& Marquez-Rios, E. (2016). Thermal gelation of myofibrillar proteins from aquatic organisms. CYTA: Journal of Food, 14(3), 502-508.

Tornberg, E. (2005). Effects of heat on meat proteins - Implications on structure and quality of meat products. Meat Science, 70(3), 493-508. PMid:22063748. http://dx.doi.org/10.1016/j.meatsci.2004.11.021 
Yang, T. S., \& Froning, G. W. (1992). Selected washing processes affect thermal gelation properties and microstructure of mechanically deboned chicken meat. Journal of Food Science, 57(2), 325-332. http://dx.doi.org/10.1111/j.1365-

2621.1992.tb05486.x

Funding: Ministério da Ciência, Tecnologia e Inovação/Conselho Nacional de Desenvolvimento Científico e Tecnológico - 430206/2016-0. Fundação de Amparo à Pesquisa do Estado de Minas Gerais - CVZ APQ-02015-15/CVZ APQ02904-17. 